\title{
The conquest of the South Pole: Importance and lessons for the present
}

La conquista del Polo Sur: Importancia y lecciones para el presente

\author{
MARCO A. MOLINA-MONTENEGRO ${ }^{1, ~ *} \&$ LUIS J. CORCUERA ${ }^{2}$ \\ ${ }^{1}$ Centro de Estudios Avanzados en Zonas Áridas (CEAZA), Facultad de Ciencias del Mar, Universidad Católica del Norte, \\ Larrondo 1281, Coquimbo, Chile \\ ${ }^{2}$ Departamento de Botánica, Universidad de Concepción, Casilla 160-C, Concepción, Chile \\ ${ }^{*}$ Corresponding author: marco.molina@ceaza.cl
}

\section{INTRODUCTION TO THE SPECIAL FEATURE “100 YEARS OF ANTARCTIC RESEARCH”}

On December 14, 1911, the Swedish Roald Amundsen, heading a group of explorers reached the South Pole. This date has become a symbol of all those great explorers that risking their lives in the most inhospitable continent in our planet, reached places that looked impossible to conquer. This date is also a symbol of the great difficulties that must be overcome to work in the Antarctic and of much that is yet to be known in the white continent. These are the reasons why Revista Chilena de Historia Natural is commemorating this important historic event with a Special Feature dedicated to Antarctic research.

The era of epic exploration in the Antarctic, such as those led by Roald Amundsen, Robert Scott, Ernest Shakleton, and many others has come to an end. This era had great unforgettable victories and defeats. The exciting race to conquer the South Pole among Amundsen and Scott left valuable lessons on the enormous difficulties to perform Antarctic exploration and the importance of planning and logistic design for any activity in the Antarctic. Perhaps, one of the best known expeditions for the magnitude of the encountered, adverse climatic conditions and importance of international cooperation is the Endurance Expedition, led by Ernest Shackleton in the period between 1914 and 1916. The loss of the Endurance, the courage of the explorers to reach Elephant Island, and the incredible determination of the leader of the expedition to achieve impress us even today. It was this determination that inspired the Chilean pilot Luis Pardo to risk the precarious ship Yelcho, performing one of the most celebrated rescue expeditions in Antarctic history. This era of great explorers, in addition to opening new routes, had the merit of drawing international attention on the great white continent and raised interest of many countries on the possible colonization, use of resources, and scientific research of Antarctic organisms, geological resources, climate, atmosphere, climatic change, and other aspects.

The difficulties and dangers of Antarctic research are still enormous in spite of the technology which is available today. Logistic costs to perform modern and safe Antarctic expeditions are very high. For this reason, the available budget is the main limitation for Antarctic research. However, in spite of the encountered difficulties, researchers have unveiled step by step the importance of Antarctic in the world's climate, ocean levels, availability of natural resources, and aspects of conservation and utilization of its flora and fauna.

\section{TRENDS IN BIOLOGICAL ANTARCTIC RESEARCH IN CHILE}

The Chilean President Gabriel Gonzalez visited the Antarctic in 1947. This visit is considered a landmark for the Chilean involvement in the Antarctic. However, the foundation of the Chilean Antarctic Institute (INACH) in 1963 is the landmark for the organized involvement of Chilean scientists in Antarctic research. From this time, a sustained effort 
to promote Antarctic research has taken place. Biological research in the Antarctic was initiated by individual scientists mainly focused on describing the taxonomic diversity of organisms. Gradually, this emphasis changed to aspects of the biology and chemical composition of these organisms. During the last decade of the twentieth century, research in the Antarctic evolved towards physiology, ecology, and conservation. Thus, different research groups were conformed to study these problems, changing from individual to collective efforts. As new more complex problems have emerged, such as global warming, multidisciplinary research groups are developing. For example, the study of individual and population responses to global warming requires a complex ensemble of ecophysiologists, ecologists, and molecular biologists. Possible biological invasions due to higher temperature and increase in scientific and touristic visitors also require a multidisciplinary approach. Moreover, the increasing pressure to study possible uses of the Antarctic biota, has led to biotechnological approaches performed by multidisciplinary research groups. In this Special Feature, some of these trends are discussed.

\section{SPECIAL FEATURE ON ANTARCTIC RESEARCH}

This Special Feature in the Revista Chilena de Historia Natural brings together seven articles that focus upon patterns and processes of the Chilean research in Antarctic topics. In their overview article, Leppe et al. (2012) shows us the events and areas of endemism during the Cretaceous of Antarctica and southern Patagonia. They further indicate that vegetation evolved under environmental conditions subject to intense volcanic and climate disturbance, but with pulses of strong cooling, suggesting that a continuous forest existed between Patagonia and South America which was shaped, during the Latest Cretaceous, by the presence of marine basins and an intermittent connection and disconnection of floral assemblages.

On the other hand, MacDonell \& Fitzsimons (2012) working in the Antarctic glaciers show how the water may be drained via channels, cracks and intergranular drainage, however the relative importance of each is not yet known. As cryconite holes are relatively nutrient-rich compared with clean glacier ice, the nature of connections between cryoconite holes are important for determining nutrient delivery both across the glacier and to the proglacial region.

Using the aerial photography from 50's decade, Hebel et al. (2012) note an arising of the opportunities for colonization on areas where ice is retreating. Research on colonization of new ice-free areas is analyzed by molecular genetics in order to decrypt and find early settlements. Finally, an analysis of conservation status in Antarctica is discussed.

In a physiological study with Antarctic plants, Navarrete et al. (2012) show a high variation in several foliar traits in two genotypes of Colobanthus quitensis. The Andean ecotype exhibited higher levels of anti-oxidants under high and medium UV-B radiation. The Antarctic ecotype exposed to UV-B and cold showed a higher damage in membranes, also a greater degree of photoinactivation. Additionally, the accumulation of a new anti-oxidant isoform was detected in plants exposed to UV-B treatment. In conclusion, the Andean ecotype presents a more effective antioxidant response against UV-B than the Antarctic ecotype.

Passing to other environment, De la Iglesia \& Trefault (2012) perform a review about the changes in eukaryote phytoplankton composition and its strong repercussion on the food webs in the Southern Ocean. The knowledge of both the diversity and variation of marine eukaryote phytoplankton in Antarctic waters is crucial for the proper understanding and predictability regarding how these environments can respond to a changing ocean.

Following in the same system, GonzálezWevar et al. (2012) provide new evidences about the differentiation processes between Antarctic and South American benthic organisms. None of the analyzed genera showed evidence for recurrent gene flow across the Antarctic Circumpolar Current since the Pliocene. Genetic comparisons indicated that Antarctic and Sub-Antarctic species were differentially affected by glacial periods. Similarly, Diaz et al. (2012) by phylogenetic relationships show a marked genetic difference between Antarctic and Sub-Antarctic congeneric species, nevertheless was confirmed the affinity of the Antarctic sea-urchin A. agasizzii with Sub- 
Antarctic species. On the other hand, some shared ecological characteristics were evident, such as the existence of an annual brooding reproductive cycle and habitat type preferences and some key morphological traits. According to the results of Diaz et al. (2012), the presence of $A$. agassizii in the Shetland Islands could be explained by a recent re-colonization from Antarctic islands located further to the north.

\section{FINAL REMARKS}

The Antarctic ecosystem is one of the most wonderful places worldwide, and possesses completely unknown places with unexplored areas. The task of knowing what species live in the ice, under ice and in the Antarctic seas is not complete and every step taken in this sense is a milestone for international science and knowledge (sensu Retamales 2010). Hence, all scientific activities conducted by different researchers represent a great contribution to enhance the Chilean Antarctic knowledge. In this sense, the Instituto Antártico Chileno (INACH) has become the main institution supporting the majority of Antarctic research through grants and logistic support. Finally, we should not forget that the main strength for Chilean researchers in the area that is projected toward the South Pole is the unparalleled opportunity that gives Antarctica to all researchers to explore the last bastion of a pristine frontier at the world (Retamales 2010). Although we are commemorating 100 years of the arrival of human beings to the South Pole, with significant advances, this not rules out that in the next century we can continue marveling with new findings in the magical Antarctic ecosystem.

ACKNOWLEDGEMENTS: We thank Patricio Camus for his valuable comments on the final version of this manuscript. We also thank Instituto Antártico Chileno (INACH) for the partial funding of this Special Feature.

\section{LITERATURE CITED}

DE LA IGLESIA \& N TREFAULT (2012) Marine photosynthetic eukaryotes in polar systems: Unveiling phytoplankton diversity and composition in Antarctic waters. Revista Chilena de Historia Natural 85: 435-443.

DÍAZ A, CA GONZÁLEZ-WEVAR, CS MATURANA, AT PALMA, E POULIN \& G KARIN (2012) Restricted geographic distribution and low genetic diversity of the brooding sea urchin Abatus agassizii (Spatangoidea: Schizasteridae) in the South Shetland Islands: A bridgehead population before the spread to the northern Antarctic Peninsula? Revista Chilena de Historia Natural 85: 457-468.

GONZÁLEZ-WEVAR CA, A DÍAZ, K GÉRARD, JI CAÑETE \& E POULIN (2012) Divergence time estimations and contrasting patterns of genetic diversity between Antarctic and southern South America benthic invertebrates. Revista Chilena de Historia Natural 85: 445-456.

HEBEL I, C GALLEGUILLOS, R JAÑA \& MDC DACASA-RÜDINGER (2012) Early knowledge of Antarctica's vegetation: Expanding past and current evidence. Revista Chilena de Historia Natural 85: 409-418.

LEPPE M, M MIHOC, N VARELA, W STINNESBECK, H MANSILLA et al. (2012) Evolution of the AustralAntarctic flora during the Cretaceous: New insights from a paleobiogeographic perspective. Revista Chilena de Historia Natural 85: 369-392.

MACDONELL SA \& SJ FITZSIMONS (2012) Observations of cryoconite hole system processes on an Antarctic glacier. Revista Chilena de Historia Natural 85: 393-407.

NAVARRETE-GALLEGOS AA， LA BRAVO, MA MOLINA-MONTENEGRO \& LJ CORCUERA (2012) Respuestas antioxidantes en dos ecotipos de Colobanthus quitensis (Caryophyllaceae) expuestos a alta radiación UV-B y baja temperatura. Revista Chilena de Historia Natural 85: 419-433.

RETAMALES J (2010) Programa Científico Antártico Nacional. Ministerio de Relaciones Exteriores, Instituto Antártico Chileno, Punta Arenas, Chile.

Editorial responsibility: Patricio A. Camus 
